\title{
Spiral cleavage and early embryology of a loxosomatid entoproct and the usefulness of spiralian apical cross patterns for phylogenetic inferences
}

\author{
Julia Merkel ${ }^{1}$, Tim Wollesen ${ }^{2}$, Bernhard Lieb ${ }^{1}$ and Andreas Wanninger ${ }^{2 *}$
}

\begin{abstract}
Background: Among the four major bilaterian clades, Deuterostomia, Acoelomorpha, Ecdysozoa, and Lophotrochozoa, the latter shows an astonishing diversity of bodyplans. While the largest lophotrochozoan assemblage, the Spiralia, which at least comprises Annelida, Mollusca, Entoprocta, Platyhelminthes, and Nemertea, show a spiral cleavage pattern, Ectoprocta, Brachiopoda and Phoronida (the Lophophorata) cleave radially. Despite a vast amount of recent molecular phylogenetic analyses, the interrelationships of lophotrochozoan phyla remain largely unresolved. Thereby, Entoprocta play a key role, because they have frequently been assigned to the Ectoprocta, despite their differently cleaving embryos. However, developmental data on entoprocts employing modern methods are virtually non-existent and the data available rely exclusively on sketch drawings, thus calling for thorough re-investigation.

Results: By applying fluorescence staining in combination with confocal microscopy and 3D-imaging techniques, we analyzed early embryonic development of a basal loxosomatid entoproct. We found that cleavage is asynchronous, equal, and spiral. An apical rosette, typical for most spiralian embryos, is formed. We also identified two cross-like cellular arrangements that bear similarities to both, a "molluscan-like" as well as an "annelid-like" cross, respectively.

Conclusions: A broad comparison of cleavage types and apical cross patterns across Lophotrochozoa shows high plasticity of these character sets and we therefore argue that these developmental traits should be treated and interpreted carefully when used for phylogenetic inferences.
\end{abstract}

Keywords: Lophotrochozoa, Embryology, Development, Ontogeny, Evolution, Phylogeny, Spiral cleavage, Molluscan cross, Annelid cross

\section{Background}

Currently, bilaterian animals are subdivided into four major groups: the supposedly basal Acoelomorpha, the Ecdysozoa (combining all molting animals such as arthropods and nematodes), the Lophotrochozoa with a trochophore-like ciliated larva (e.g., Annelida, Entoprocta, Mollusca, Platyhelminthes), and Deuterostomia (including chordates, hemichordates and echinoderms)

\footnotetext{
* Correspondence: andreas.wanninger@univie.ac.at

¿University of Vienna, Dept. of Integrative Zoology, Althanstrasse 14, 1090 Vienna, Austria

Full list of author information is available at the end of the article
}

[1-4]. Despite ongoing efforts, the interrelationships of the phyla that nest within the Lophotrochozoa remain unresolved [5,6]. Entoprocta is a phylum that has been proposed to belong to a clade of spirally cleaving animals, the so-called Spiralia, which together with its suggested sister group, the Lophophorata (Ectoprocta, Brachiopoda, and Phoronida), forms the Lophotrochozoa [1]. Typically, entoprocts are microscopic, mostly marine, sessile metazoan animals. Its approximately 150 hitherto described species are divided into four subgroups, the solitary (and supposedly basal) Loxosomatidae and the colonial Barentsiidae, Pedicellinidae, and
C Biomed Central

() 2012 Merkel et al; licensee BioMed Central Ltd. This is an Open Access article distributed under the terms of the Creative Commons Attribution License (http://creativecommons.org/licenses/by/2.0), which permits unrestricted use, distribution, and reproduction in any medium, provided the original work is properly cited. 
Loxocalypodidae [7]. Their adult gross morphology is characterized by a ciliated tentacle crown, which surrounds both the mouth and the anus. The calyx houses the reproductive organs, mostly one pair of protonephridia, and the cerebral ganglion. Entoprocts reproduce asexually by budding, as well as sexually, whereby two major larval types can be recognized, namely the creeping, supposedly basal, lecithotrophic and the more common swimming, planktotrophic larval type [8]. Metamorphosis is very complex and often involves settlement and adhesion with the frontal body region to the substrate as well as rotation of the gut [9].

Morphological and molecular analyses have proposed several phylogenetic hypotheses concerning entoproct interphyletic relationships. Traditionally, Entoprocta and Ectoprocta have been comprised to form the monophyletic Bryozoa (Bryozoa-concept), based on a metamorphosing larval stage with a completely retracted and cavity-enclosed prototroch as well as additional common features during metamorphosis [8,9]. This hypothesis has been revived by a recent molecular study [10], although subsequent analyses of partly the same authors are far less clear [11]. The cryptic Cycliophora, one of the most recently erected phyla [12], have also argued to be associated with Entoprocta and Ectoprocta, notably as a monophyletic assemblage termed "Polyzoa" $[13,14]$, while other authors suggest a sister group relationship of Cycliophora and Entoprocta alone $[15,16]$. On the contrary, the recently proposed Tetraneuraliaconcept has strengthened the so-called Lacunifera- or Sinusoida- hypothesis, suggesting a monophyletic assemblage of Entoprocta and Mollusca based on numerous larval and adult autapomorphies [4,17-19]. Resembling a mosaic of larval and adult molluscan characters, the entoproct creeping-type larva shares a number of morphological traits with the polyplacophoran trochophore, including a highly complex apical organ with eight centrally located flask-shaped and several peripheral cells, as well as a typical molluscan-like tetraneurous condition of longitudinal nerve cords [4,19-21]. Additional shared characters are, among a total set of nine, the distinct creeping foot, a large pedal gland, frontal cirri, and a ventrally intercrossing dorsoventral musculature $[4,19,20]$. Despite the spiral cleavage pattern, which has traditionally been used to unite polyclad flatworms, nemerteans, annelids, and molluscs as "Spiralia" [22], other developmental characters, such as the cellular arrangement into an "apical cross pattern" during early embryogenesis, have been used to infer protostome interrelationships. For a long time, only two cross patterns had been clearly defined, namely the molluscan and the annelid cross, respectively. Since a seemingly "molluscan-type" cross pattern had also been reported for sipunculans, a close relationship to molluscs was suggested [23]. Recently, additional cross patterns, such as a nemertean cross, have been described [24]. For entoprocts, a spiral cleavage pattern has been mentioned in the literature and is often referred to in textbooks, but its documentation is restricted to only a few sketch drawings [25-27]. Apical cross patterns, which would be expected for a spirally cleaving taxon, have not been reported by these studies.

In order to fill the significant gaps in knowledge concerning entoproct early embryology, we herein describe the development of a representative of the supposedly basal entoproct genus Loxosomella by applying immunochemistry and confocal microscopy. Using our detailed description of the early cleavage pattern, we also clarify whether or not a distinct "cross pattern" is present in this species. These data are discussed with those available for other lophotrochozoans in order to assess their suitability for phylogenetic inferences.

\section{Methods}

\section{Animals and fixation}

Populations of an undescribed, brooding loxosomatid entoproct belonging to the genus Loxosomella (Claus Nielsen, pers. comm.) were collected in July 2007 from tubes of the maldanid polychaete, Axiothella rubrocincta, which inhabits the intertidal mud flats of False Bay, San Juan Island, USA. Up to 20 embryos of all developmental stages can be found in one mother individual. From approximately 100 mother animals, we analyzed four individuals each for the 1-, 2-, 4- to 5-, and 8-cell stages, seven embryos that had between eight and 16 cells, and one 21-cell embryo. Approximately 50 embryos were found at the apical rosette stage and three gastrulae were investigated. Numerous swimmingtype larvae - obviously shortly before release - were retrieved, indicating the healthy condition of the adults and their developmental stages. The results obtained were highly consistent among the individuals of each developmental stage. Accordingly, the spiral-type cleavage pattern was found in all embryos investigated, although the shape (spherical versus more oval) varied between individuals.

In order to remove the embryos from the mother animal, the tentacle crown was cut open using insect needles. Prior to fixation, adult individuals carrying embryos were relaxed in $7 \% \mathrm{MgCl}_{2}$ and removed from the polychaete tubes. Fixation was carried out using a solution of $4 \%$ paraformaldehyde (PFA) in $0.1 \mathrm{M}$ phosphate buffered saline (PBS) for $1 \mathrm{~h}$ at room temperature. After fixation, the specimens were washed in 0.1 M PBS $(3 \times 15 \mathrm{~min})$ and stored in $0.1 \mathrm{M}$ PBS containing $0.1 \%$ $\mathrm{NaN}_{3}$ at $4^{\circ} \mathrm{C}$.

A reference specimen, determined by Dr. Claus Nielsen (Copenhagen) is deposited at The Natural History 
Museum of Denmark, Copenhagen (registration tag ZMUC-ENT-27). In addition, the COI gene of our study specimen was partially sequenced and the $710 \mathrm{bp}$ sequence deposited in GenBank (acc. \# JQ614997).

\section{Immunocytochemistry, data generation, and analysis}

After fixation and storage, the embryos were permeabilized in $0.1 \mathrm{M}$ PBS with $0.1 \%$ Triton X-100 (PBT) for 1 h. F-actin was labeled using a 1:20 dilution of Alexa Fluor 488 phalloidin (Invitrogen, Molecular Probes, Eugene, OR, USA) in PBT. For nucleic acid staining, $10 \%$ DAPI (Invitrogen, Taastrup, Denmark) was added and the samples were incubated for 20-24 h at room temperature. Then, the embryos were washed in $0.1 \mathrm{M}$ PBS $(3 \times 15 \mathrm{~min})$ and mounted in Fluoromount $\mathrm{G}$ (Southern Biotech, Birmingham, AL, USA) on glass slides. $5 \mu \mathrm{l}$ of DAPI (Invitrogen) was added to the embedding medium in order to enhance the signal strength of the nucleic acid staining. The samples were examined using a Leica DM RXE 6 TL fluorescence microscope equipped with a TCS SP2 AOBS laserscanning device (Leica Microsystems, Wetzlar, Germany). The optical sections had a Z-step size of 0.45-0.55 $\mu \mathrm{m}$. Resulting stacks were merged into projection images with greater focal depth. 3D reconstructions were generated from the confocal datasets using the image processing software Imaris 5.7.2 (Bitplane AG, Zürich, Switzerland).

\section{Results}

\section{General aspects of entoproct reproduction}

The brood pouch of the loxosomatid species investigated herein is located in the calyx and contains up to 20 embryos (Figure 1). Every embryo is surrounded by a thin membrane. Each membrane tapers in a strand which is connected to the strands of other embryos. Later embryonic stages are located in the anterior region of the brood chamber. The earliest developmental stages are found in the posteriormost part of the brood pouch. Due to the high yolk content, early embryos appear opaque and non-transparent. Released larvae are planktonic and of the swimming-type with a weakly developed foot sole posterior to the prototroch (see [8]).

\section{Cleavage and gastrulation in Loxosomella sp}

Fertilized eggs form a polar body which appears at the animal pole of the embryo (Figure 2A-C). In two-cell stages, both cells are equal in size and show two polar bodies, one on the animal pole and one shifted by approximately $90^{\circ}$ relative to the first one (Figure 2D; one polar body is obscured in the $3 \mathrm{D}$ reconstructions shown in $2 \mathrm{E}$ and F). Second cleavage results in four cells with three polar bodies. Since all cells are approximately equal in size, an assignment of individual cells

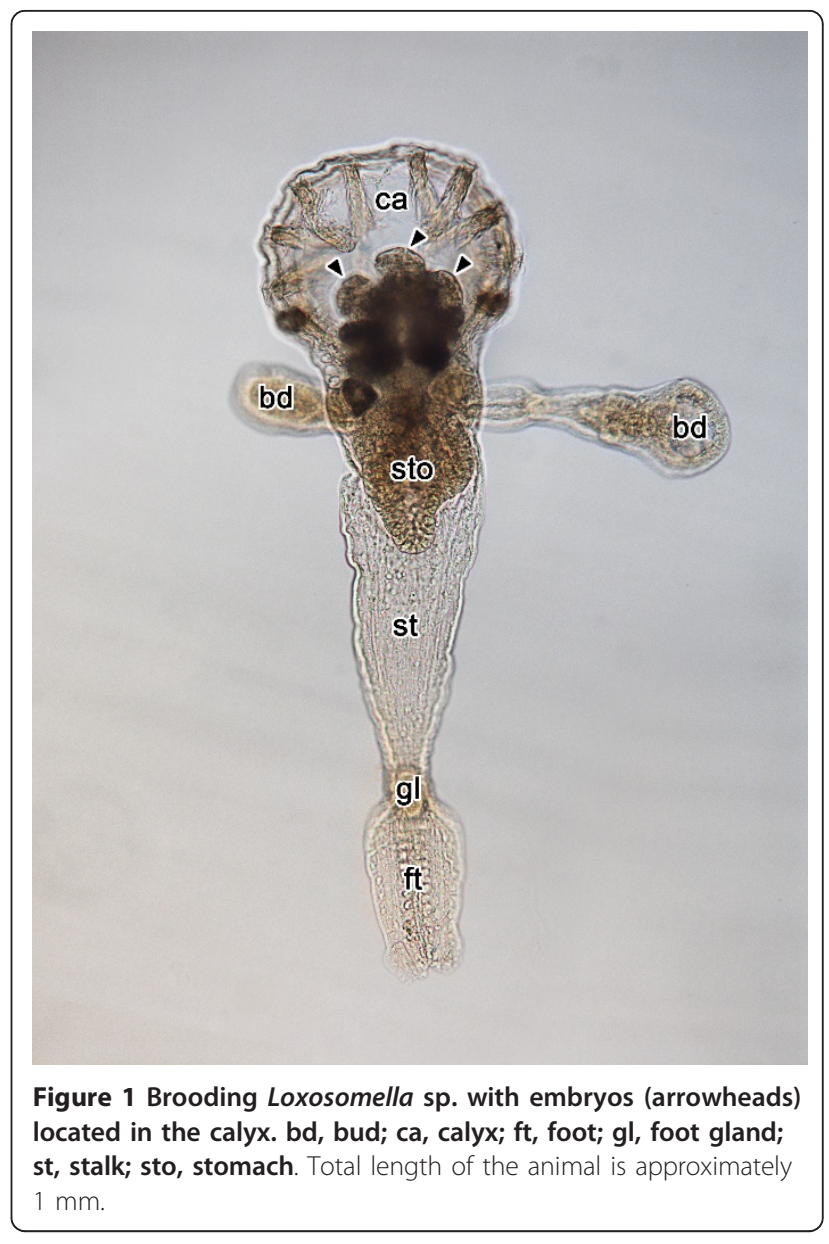

("macromeres") to specific quadrants appears difficult. Shortly after second cleavage, a fifth cell (1q) is already present and demonstrates the asynchronicity of early cleavage in our study species (Figure 2G-I). After third cleavage, eight cells have formed and only two polar bodies can be observed. Applying the nomenclature of Conklin (1897) [28], third cleavage results in the "macromere" quartet $1 \mathrm{Q}$ and the "micromere" quartet 1q. All cells of the first micromere quartet are equal in size and of approximately the same size as the macromere cells (Figure 2J-L). The blastula of the 21-cell stage is flattened and ellipsoid-shaped. All four macromeres (red cells, Figure 2N, O) are equal in size and nearly twice as large as the four micromeres (blue cells, Figure $2 \mathrm{~N}, \mathrm{O}$ ), each situated above the cleavage furrow of two macromeres. A second micromere quartet (light blue cells, Figure $2 \mathrm{~N}, \mathrm{O}$ ) is located on top of these micromeres, with similar cell size as the latter (Figure 2M-O). A third quartet of micromeres (purple cells, Figure $2 \mathrm{~N}, \mathrm{O}$ ) rests upon the macromeres. Its cells are slightly larger than the micromeres of the other two quartets. A single cell of a fourth micromere quartet (yellow cell, Figure $2 \mathrm{~N}, \mathrm{O}$ ) is situated close to the 

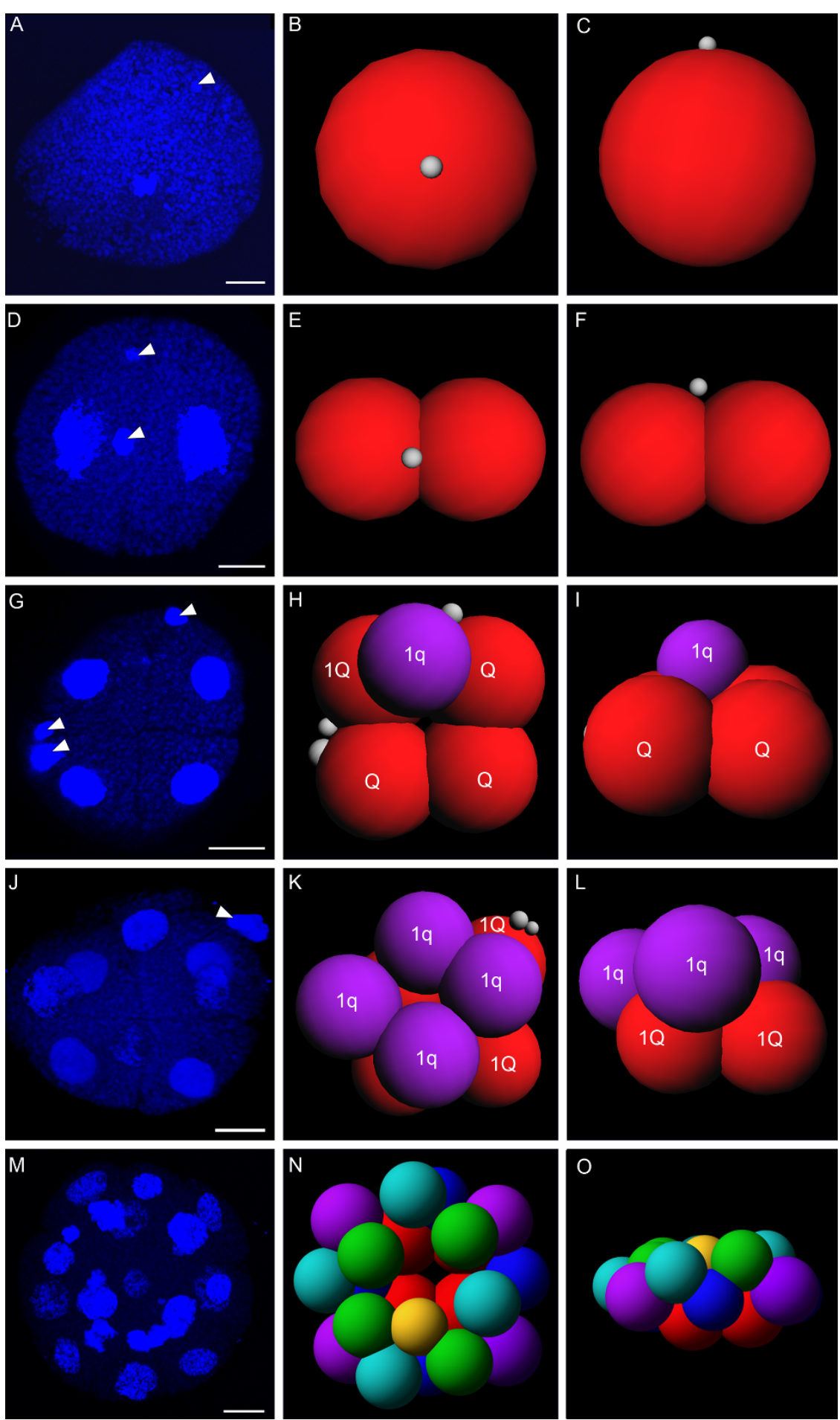

Figure 2 Confocal micrographs and 3D reconstructions of early cleavage stages of Loxosomella sp. Scale bars: $10 \mu \mathrm{m}$. left column: Nucleic acid staining (blue). A, C, F, I, L, O: lateral view; B, D, E, G, H, J, K, N: animal view; M: vegetal view. Polar bodies are indicated by arrowheads. Middle and right column: 3D reconstructions, middle column: animal view, right column: lateral view. grey: polar bodies, red: "macromere" quartet cells (nQ cells); purple, blue, light blue, green, yellow: "micromere" quartet cells (nqn cells). A-C: Fertilized oocyte prior to first cleavage. One polar body is present on the animal side of the embryo. D-F: Two-cell stage. A second polar body appears shifted by $90^{\circ}$ relative to the first polar body. The macromeres are equal in size. Second polar body obscured by the red cells in $\mathbf{E}$ and $\mathbf{F}$. G-I: Five-cell stage. Three polar bodies are present. Cleavage is asynchronous and the fifth cell (purple) lies between two Q cells (red) in a cleavage furrow. J-L: Eight-cell stage. Two polar bodies are present and located next to the vegetal, slightly unequal $1 \mathrm{Q}$ cells (red). Each cell of the first "micromere" quartet $1 \mathrm{q}$ (purple) is located in a cleavage furrow of two $1 \mathrm{Q}$ cells. M-O: 21-cell-stage. Cleavage is asynchronous, cells are different in size. 
animal pole (Figure 2M-O). At the 36-cell stage, the embryo exhibits four additional, smaller cells, which form an apical rosette on the animal pole. This apical rosette directly faces the macromere quartet on the vegetal side of the embryo (Figure 3B, C). In the 43-cell stage (Figures 3D-F, 4A) and the 51-cell stage (Figure $3 \mathrm{G}-\mathrm{I})$, respectively, cells surrounding the apical rosette are arranged in two different cross-shaped patterns (Figures 3D, E, G, 4A). The first cross pattern results from interconnecting rosette cells which lie opposite to each other, resulting in a pattern that closely resembles a molluscan cross. The second pattern is formed by the peripheral rosette cells and appears very similar to a typical "annelid cross" (Figures 3D, E, G, 4A). Overall, cleavage in the Loxosomella species investigated herein can be characterized as holoblastic, asynchronous, equal, and spiral. The gastrula stage elongates somewhat along the animal-vegetal axis and shows bilateral symmetry (Figure 3J-L). It consists of approximately 100-110 cells. A blastopore was slightly visible as a small vent on the vegetal side of the 107-cell stage (Figure 3J-L).

\section{Discussion}

Most spiralian lophotrochozoans are characterized by a spiral cleavage pattern, which is mainly defined by (1) the "spiral" arrangement of subsequent embryonic cells (= blastomeres), whereby cells of an upper tier of an embryo come to lie over the cleavage furrow of the lower tier; and (2) formation of a so-called "mesentoblast", which later gives rise to the endomesoderm from the $4 \mathrm{~d}$-cell $[7,29]$. Despite these overall similarities between spirally cleaving species, the cleavage program is subject to great variability [30], e.g. concerning the size of cells (equal or unequal), regularity (synchronous or asynchronous), direction of cleavage (clockwise vs. counter-clockwise), morphological arrangement of apical cross patterns, or cell fates. In the following, we summarize the various spiralian cleavage phenotypes and discuss them in an evolutionary context in the light of the data presented herein for the entoproct Loxosomella sp.

\section{Cleavage in molluscs}

Most molluscs, except for yolk-rich "higher" gastropods and cephalopods, show a more or less "typical" spiral cleavage pattern [31-36]. Cleavage may be equal or unequal. Some species, such as the gastropod Ilyanassa obsoleta and the scaphopod Antalis entalis (formerly Dentalium dentale), form polar lobes which fuse with the D-quadrant of the early embryo [29,33,37]. Although the formation of the first micromere quartet typically appears in a clockwise direction in most taxa, including the supposedly basal solenogaster Epimenia babai [35], the polyplacophoran Stenoplax heathiana (formerly
Ischnochiton heathiana; [32]), the scaphopod Antalis entalis [33], as well as the gastropods Limax [31], Crepidula [28,38], Patella [39], and Ilyanassa [40], a counterclockwise formation is sometimes found, e.g., in the bivalve Dreissena polymorpha [41] or in gastropods with sinistrally coiled shells such as Planorbis trivolvis [42], Physa heterostropha [43], or Lymnaea stagnalis [44]. Accordingly, it appears that in shell-bearing gastropods, the chirality of cleavage is strictly correlated with the direction of shell coiling [43-45]. In contrast to the sinistrally coiled gastropod species mentioned above, fourth cleavage takes place in a counter-clockwise direction $[28,29,31,32,35,39]$.

A typical spiralian feature develops in the following cleavage stages of different taxa, whereby derivatives of the first micromere quartet form the apical $\left(1 \mathrm{q}^{111}\right)$ and peripheral rosette $\left(1 \mathrm{q}^{112}\right)$. The apical rosette gives rise to the so-called "molluscan cross", whereby its arms are formed by the progenies of the $1 \mathrm{q}^{12}$-cells. The tips of the molluscan cross are represented by second micromere quartet cells $\left(2 \mathrm{q}^{1}\right)$ and their progenies $[28,46]$. However, variations in the morphology of the cross pattern occurs among the various molluscan subclades. For example, Stenoplax heathiana [32] exhibits relatively large cross cells $\left(1 \mathrm{q}^{121}\right)$ as well as pointed peripheral rosette cells which are slightly larger than cells of the apical rosette (Figure $4 \mathrm{C}$ ). In the basal gastropods Patella caerulea [47] and Patella vulgata [39], peripheral and apical rosette cells are similar in size and shape and slightly smaller than cells of the arms of the cross (Figure 4D), while a distinct cross pattern was not found in embryos of Epimenia [48] (Figure 4B). Cross formation in the scaphopod Antalis is characterized by a compressed pentagonal-shaped apical cell $1 \mathrm{~d}^{111}$, which contacts the cell $1 c^{112}$ of the $\mathrm{C}$-arm belonging to the molluscan cross [33]. Although most bivalves do not show a molluscan cross pattern during development [49], a molluscan cross seems to be present in the equal cleaving, basal protobranch Solemya reidi, but probably not in the closely related protobranchs Acila, Nucula, and Yoldia [50-53]. Accordingly, such a cross pattern may not even be part of the ancestral bivalve bodyplan.

\section{Cleavage in annelids (including sipunculans)}

Embryos of the polychaete Nereis [46], the echiuran Urechis caupo [55], the sipunculan Phascolosoma [56,57], the oligochaete Bdellodrilus philadelphicus [58], and the leech Theromyzon tessulatum [59] display a holoblastic, spiral cleavage pattern. Cleavage may be equal or unequal. Polar lobe formation is mainly found in polychaetes (e.g. Hydroides hexagonus) [60]. The condition of the typical spiralian eight cell stage with small micromeres and large macromeres and a clockwise formation of the first micromere quartet [30] appear to 

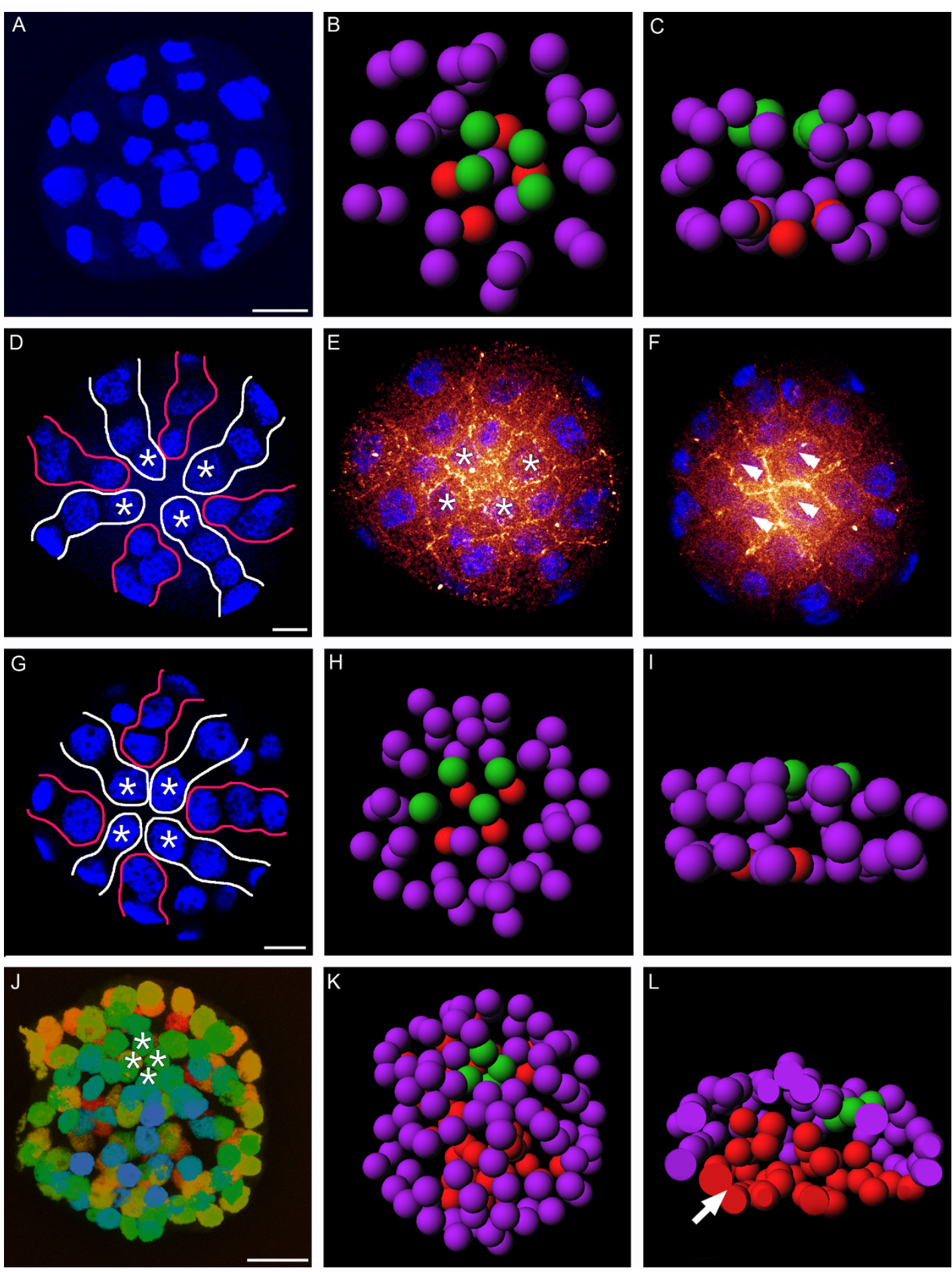

Figure 3 Confocal micrographs and 3D reconstructions of blastula and gastrula stages of Loxosomella sp. "Apical cross patterns" are indicated by white and red lines in $\mathbf{D}$ and $\mathbf{G}$. Apical rosette cell nuclei are marked with asterisks in $D, E, G, J$ and vegetal "macromere"

quartet cells by double arrowheads in F. Scale bars: $10 \mu \mathrm{m}$. A, D, G: Nucleic acid staining (blue). E, F: Nucleic acid (blue) and F-Actin staining (red). J: Nucleic acid staining shown as depth-coded confocal projection. A: vegetal view, D, E, G, J: animal view, F: vegetal view. B, C, H, I, K, L: 3D reconstructions. $\mathbf{B}, \mathbf{H}, \mathbf{K}$ : animal view, $\mathbf{C}, \mathbf{I}, \mathbf{L}$ : lateral view. red: "macromere" quartet (i.e. vegetal) cell nuclei; green: (derivatives of) apical rosette cell nuclei; purple: other cell nuclei. A-C: 36-cell stage. D-F: 43-cell stage. D: Cells surrounding the apical rosette (asterisks) show both, a molluscan- and an annelid-like cross pattern. G-I: 51-cell stage. J-L: Gastrula stage (107 cells). J: Derivatives of apical rosette cells lie in a lower plane than the surrounding cells. K, L: Gastrulation. Vegetal cells (red), blastocoel (arrow). 


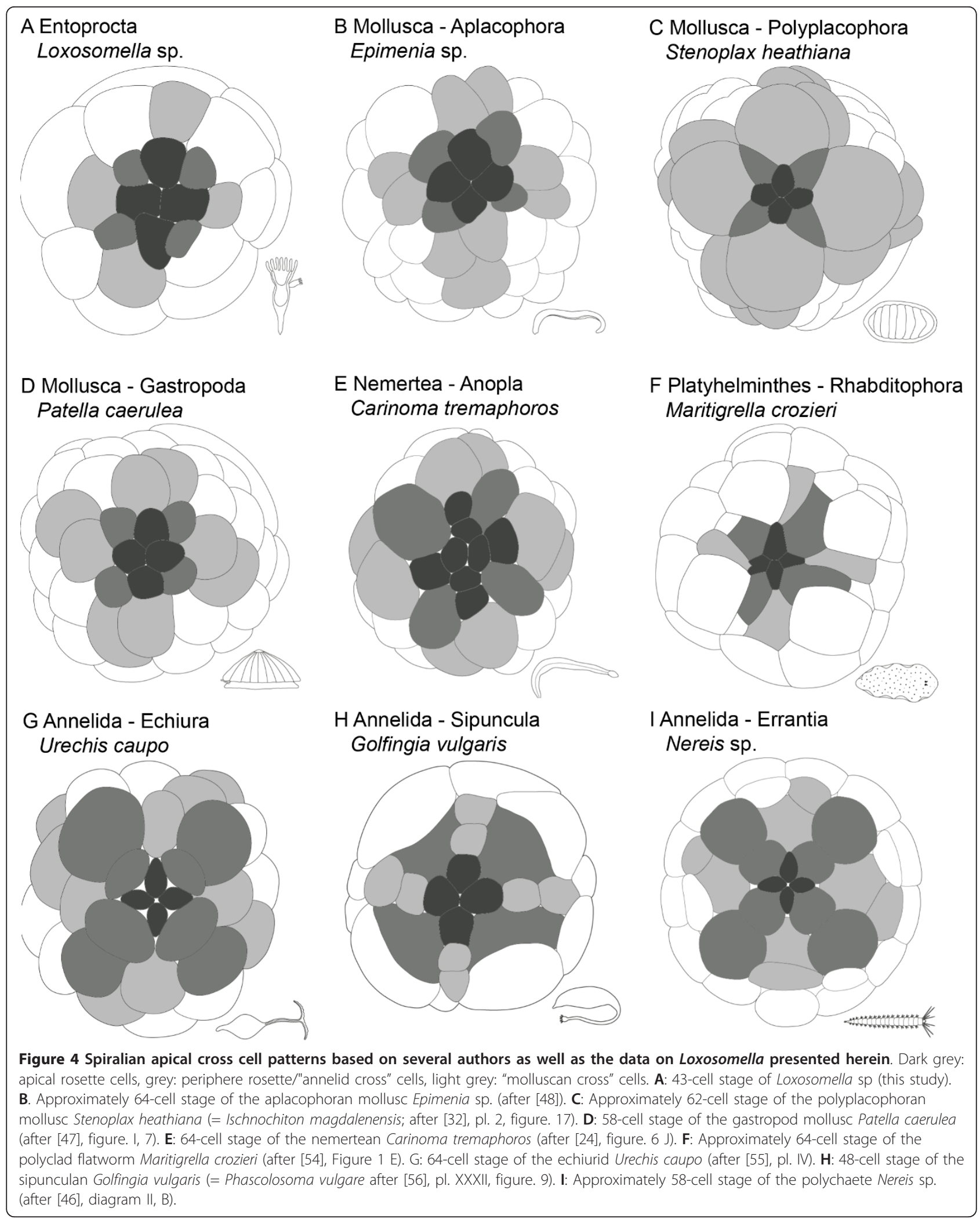


have been modified in various taxa. In the sipunculans Themiste pyroides and Phascolosoma agassizii, the micromere $1 \mathrm{~d}$ is larger than the blastomeres of the $\mathrm{A}$, $\mathrm{B}$, and $\mathrm{C}$ quadrant, and the macromere $1 \mathrm{D}$ is the largest of all cells [57]. First quartet micromeres are budded off in a clockwise direction [57,61]. In the leech Theromyzon tessulatum and the oligochaete Tubifex rivulorum, the micromeres of the first quartet are exceptionally small. While the micromeres $1 \mathrm{a}, \mathrm{c}, \mathrm{d}$ are formed in a clockwise direction, $1 \mathrm{~b}$ is budded off counter- clockwise [59]. For polychaetes, a counter-clockwise formation of first quartet micromeres has so far only been reported for the serpulid Hydroides elegans [62]. First quartet micromeres of the echiurid Urechis caupo are formed in a clockwise direction [55].

The annelid cross is a seemingly common character of echiurans, clitellates, and polychaetes $[63,64]$, whereby the peripheral rosette cells $1 \mathrm{q}^{112}$ constitute its founding cells $[28,46]$. However, if 64-cell stages are compared, a typical "annelid cross" is only present in a few taxa such as the echiuran Urechis caupo [55] (Figure 4G), the polychaetes Polygordius sp. [65], Amphitrite ornata [66], and Nereis sp. [46] (Figure 4I), as well as the leech Theromyzon tessulatum [67]. Annelid cross cells of Urechis caupo and Nereis sp. are much larger than the apical rosette cells. In both, the more peripherally located cells $1 \mathrm{q}^{1122}$ are slightly larger than their centrally located sister cells $1 \mathrm{q}^{1121}$ (Figure 4G, I). Embryos of T. tessulatum show a very indistinct cross pattern. Together with other small micromeres, the annelid cross cells are embedded in the furrows of the comparatively huge macromeres (Figure 494 in [67]). Compared to Nereis sp. (Figure 4I), the division of peripheral rosette cells in Chaetopterus pergamentaceus is oblique and results in an indistinct cross pattern [66].

The first description of a cross stage in sipunculans was performed on Phascolosoma vulgare (= Golfingia vulgaris; [56,61]; Figure $4 \mathrm{H}$ herein), which is still cited as proof for a molluscan-type cross pattern in a sipunculan $[23,68]$, and thus as an indication for a molluscsipunculan sister relationship. However, a number of independent developmental and molecular studies strongly argue in favour of a monophyletic annelidsipunculan assemblage $[10,11,69-75]$. Although never explicitly stated for sipunculans, the arrangement of the peripheral rosette cells closely resembles the arrangement of an early stage annelid cross, whereby the sipunculan peripheral rosette cells are considerably larger than their molluscan counterparts (Figure 4). However, convincing recent data on the early embryology of sipunculans are lacking, and thus prevent a final statement as to whether or not an annelid or molluscan cross-like pattern is part of the sipunculan groundplan.

\section{Cleavage in other lophotrochozoans}

Nemertean cleavage is holoblastic, equal, and spiral [24,76,77]. First quartet micromeres of Cerebratulus lacteus [78] and Carinoma tremaphoros [24] are larger than the macromeres. A so-called "nemertean cross" is found in Carinoma tremaphoros ([24]; Figure 4E herein) and Emplectonema gracile [24]. It is formed by accelerated cell divisions of the apical rosette, which so far has only been reported from nemertean species. Nemertean peripheral rosette cells are relatively large compared to the small apical rosette cells (Figure 4E). Polyclad platyhelminths such as Maritigrella crozieri and Hoploplana inquilina show a quartet, equal and spiral cleavage pattern $[54,79]$. In both species, fourth quartet micromeres are very large compared to the relatively small macromeres [54]. Morphologically, the apical and peripheral rosette cells of the 32- to 64-cell stage of the polyclad flatworm Maritigrella crozieri could be interpreted as both, a molluscan and an annelid cross pattern, respectively [54]. Although the progenitor cells of the apical and peripheral rosettes have not yet divided at this stage, blastomeres of the 32-cell stage ("third quartet"stage) of $H$. inquilina form an apical cross-like pattern (see $[79,80])$. In Maritigrella crozieri, peripheral rosette cells are slightly elongated and more than twice as large as the apical rosette cells (Figure 4F).

Developmentally, ectoprocts, phoronids, and brachiopods are unique within the lophotrochozoans because they exhibit a radial cleavage pattern [81-84]. A spiraltype cleavage pattern has been proposed for the phoronid Phoronopsis viridis [85] and the brachiopod Terebratulina septentrionalis [86] by some classical studies, although these data are highly questioned by recent investigations and may be artifactual due to compression of the embryos $[81,85]$.

\section{Cleavage in entoprocts}

The Loxosomella species investigated herein cleaves holoblastic, asynchronous, equal, and spiral, whereby all cells are of approximately the same size until third cleavage. Indicated by the degree of shifting of the micromere cells relative to the macromere cells, the first micromere quartet is formed in a clockwise direction (Figure 2G-L). Accordingly, comparative morphology of the cleavage stages investigated herein clearly shows that our study species exhibits typical spiral cleavage. Following the rule of alternation, in Loxosomella, the second quartet micromeres (blue cells, Figure $2 \mathrm{~N}, \mathrm{O}$ ) rotate in a counter-clockwise direction until they occupy the furrows between the macromeres (red cells, Figure $2 \mathrm{~N}, \mathrm{O}$ ). As a consequence, cells of the first micromere quartet are turned back over the centre of each macromere (cf. [28]). Division of the first micromere quartet results in 
the $1 \mathrm{q}^{1}$ - and $1 \mathrm{q}^{2}$-quartets (purple cells, Figure $2 \mathrm{~N}, \mathrm{O}$ ). The light blue and green colored cells are probably derivatives of the first micromere cells $1 \mathrm{q}^{1}$, while the yellow cell is likely to be a derivative of the $1 \mathrm{q}^{11}$ cell (Figure $2 \mathrm{~N}, \mathrm{O})$. Morphologically, the apical cross pattern in the 43-cell stage of Loxosomella sp. exhibits two cross-like patterns, which show similarities to both a "molluscan" and an "annelid cross", respectively (see also [87]), thus supporting closer affinity of Entoprocta with these spiralian taxa than with Ectoprocta. Observations on the colonial entoproct Pedicellina echinata (= Pedicellina cernua) report both, a slightly unequal [25] and an equal cleavage pattern [26]. Sketch drawings of the first cleavage stages of Loxosoma leptoclini were interpreted as showing equally-sized blastomeres [26]. However, since we were not able to trace cell genealogy in our study species, a concluding statement concerning homology between these "entoproct crosses" and the annelid and/or molluscan crosses cannot be given at present. A comparison of the various spiralian-type cleavage patterns, however, does demonstrate the morphological plasticity of the "cross-type" cellular arrangement in the various spiralian representatives, and thus shows that phylogenetic conclusions based on these embryonic morphotypes alone should be treated with utmost care.

\section{Conclusions}

Although it has repeatedly been proposed that the "molluscan cross" constitutes a pattern that is only found in molluscs and closely related sister groups $[23,88]$, similar cross patterns are also present in other spiralian animals including annelids, nemerteans, and flatworms $[24,87,89]$ (cf. Figure 4). The arrangement of the annelid and nemertean cross cells resembles a generation of cells which usually appears during the $7^{\text {th }}$ cleavage cycle, while molluscan cross cells are formed during the $6^{\text {th }}$ division. Since the annelid and nemertean cross is formed earlier in development, the formation of both cross patterns is distinct to these phyla and is not found in 64-cell stages of molluscan embryos. Accordingly, due to their variation even between closely related species, a typical "molluscan" or "annelid" cross pattern cannot reliably be proposed at present, thus rendering these cleavage morphologies phylogenetically uninformative. However, we suggest that an embryonic stage with a cross-like pattern was present in the last common ancestor of Spiralia. The cleavage pattern of the entoproct Loxosomella sp. investigated herein shows typical spiralian features, such as the spiral arrangement of blastomeres around the animal-vegetal axis of the embryo and the presence of a cross-like pattern, thus indeed rendering entoprocts "true" spiralians.

The currently widely held view that the radially cleaving Ectoprocta is not the sister group of Entoprocta is well supported by our data and strongly suggests the inclusion of Entoprocta within Spiralia. This is also in agreement with the Tetraneuralia-hypothesis, which suggests a Mollusca-Entoprocta clade [4] and argues against the so-called Polyzoa-concept (Ectoprocta + Entoprocta + Cycliophora; see [14]). The latter scenario would either imply independent evolution of spiral cleavage in Entoprocta and the remaining Spiralia or secondary loss of spiral cleavage in Ectoprocta (data on cleavage in Cycliophora are still lacking). On a deeper evolutionary scale, the classical subdivision of Lophotrochozoa into Spiralia and Lophophorata suggests either a spiral or a radial cleavage pattern for the last common lophotrochozoan ancestor. The duet-spiral-type of cleavage in the supposedly basal bilaterians, the acoels, may favour a scenario where a modification of this cleavage pattern might have resulted in the quartet-spiral cleavage pattern of the ur-lophotrochozoan, with a secondary modification in the lophophorates. At present, such evolutionary deductions remain speculative, however, due to the lack of a reliable phylogeny for internal lophotrochozoan relationships and the unresolved question concerning the last common lophotrochozoan and bilaterian ancestor.

\section{Acknowledgements}

We are indebted to the Friday Harbor Laboratories for their hospitality during the stay of TW while collecting Loxosomella. JM is grateful to Lisbeth Haukrogh and Henrike Semmler (both Copenhagen) for help with immunocytochemistry, confocal microscopy, and the Imaris software. This work was supported by a grant of the German Science Foundation to BL (Li998/9-1), the Feldbausch Stiftung (University of Mainz), and the Inneruniversitäre Forschungsförderung (University of Mainz), both to BL.

\section{Author details}

'Johannes Gutenberg University, Institute of Zoology, 55099 Mainz, Germany. ${ }^{2}$ University of Vienna, Dept. of Integrative Zoology, Althanstrasse 14, 1090 Vienna, Austria.

\section{Authors' contributions}

JM performed research and drafted the manuscript. TW acquired the study material and helped with immunostaining and confocal microscopy. BL contributed to data interpretation. AW designed the study, supervised research, contributed to data interpretation, and improved the manuscript draft. All authors contributed to and approved the final version of the manuscript.

Received: 20 October 2011 Accepted: 29 March 2012

Published: 29 March 2012

\section{References}

1. Halanych KM, Bacheller JD, Aguinaldo AM, Liva SM, Hillis DM, Lake JA: Evidence from $18 \mathrm{~S}$ ribosomal DNA that the lophophorates are protostome animals. Science 1995, 267:1641-1643.

2. Aguinaldo AMA, Turbeville JM, Linford LS, Rivera MC, Garey JR, Raff RA, Lake JA: Evidence for a clade of nematodes, arthropods and other moulting animals. Nature 1997, 387:489-493.

3. Halanych KM: The new view of animal phylogeny. Ann Rev Ecol Evol Syst 2004, 35:229-256.

4. Wanninger A: Shaping the things to come: Ontogeny of lophotrochozoan neuromuscular systems and the Tetraneuralia concept. Biol Bull 2009, 216:293-306. 
5. Dunn CW, Hejnol A, Matus DQ, Pang K, Browne WE, Smith SA, Seaver E, Rouse GW, Obst M, Edgecombe GD, Sørensen MV, Haddock SHD, SchmidtRhaesa A, Okusu A, Kristensen RM, Wheeler WC, Martindale MQ, Giribet G: Broad phylogenomic sampling improves resolution of the animal tree of life. Nature 2008, 452:745-749.

6. Yokobori S, Iseto T, Asakawa S, Sasaki T, Shimizu N, Yamagishi A, Oshima T, Hirose E: Complete nucleotide sequences of mitochondrial genomes of two solitary entoprocts, Loxocorone allax and Loxosomella aloxiata: Implications for lophotrochozoan phylogeny. Mol Phylogenet Evol 2008, 47:612-628.

7. Nielsen C: Some aspects of spiralian development. Acta Zool (Stockholm) 2010, 91:20-28.

8. Nielsen C: Entoproct life-cycles and the entoproct/ectoproct relationship. Ophelia 1971, 9:209-341.

9. Nielsen C: Animal evolution: Interrelationships of the living phyla Press, Oxford: Oxford Univ; 2001.

10. Hausdorf B, Helmkampf M, Meyer A, Witek A, Herlyn H, Bruchhaus I, Hankeln T, Struck TH, Lieb B: Spiralian phylogenomics supports the resurrection of Bryozoa comprising Ectoprocta and Entoprocta. Mol Biol Evol 2007, 24:2723-2729.

11. Hausdorf B, Helmkampf M, Nesnidal MP, Bruchhaus I: Phylogenetic relationships within the lophophorate lineages (Ectoprocta, Brachiopoda and Phoronida). Mol Phylogenet Evol 2010, 55:1121-1127.

12. Funch $P$, Kristensen RM: Cycliophora is a new phylum with affinities to Entoprocta and Ectoprocta. Nature 1995, 378:711-714.

13. Cavalier-Smith T: A revised six-kingdom system of life. Biol Rev 1998, 73:203-266.

14. Hejnol A, Obst M, Stamatakis A, Ott M, Rouse GW, Edgecombe GD, Martinez $P$, Baguñà J, Bailly $X$, Jondelius U, Wiens M, Müller WEG, Seaver E, Wheeler WC, Martindale MQ, Giribet G, Dunn CW: Assessing the root of bilaterian animals with scalable phylogenomic methods. Proc $R$ Soc Lond B 2009, 276:4261-4270.

15. Passamaneck $Y$, Halanych KM: Lophotrochozoan phylogeny assessed with LSU and SSU data: evidence of lophophorate polyphyly. Mol Phylogenet Evol 2006, 40:20-28.

16. Meyer A, Todt C, Mikkelsen NT, Lieb B: Fast evolving 18S rRNA sequences from Solenogastres (Mollusca) resist standard PCR amplification and give new insights into mollusc substitution rate heterogeneity. BMC Evol Biol 2010, 10:70

17. Ax P: Das System der Metazoa. 2 edition. Stuttgart: Gustav Fischer; 1999.

18. Haszprunar G: Is the Aplacophora monophyletic? A cladistic point of view. Amer Malac Bull 2000, 15:115-130.

19. Haszprunar $G$, Wanninger $A$ : On the fine structure of the creeping larva of Loxosomella murmanica: additional evidence for a clade of Kamptozoa (Entoprocta) and Mollusca. Acta Zool (Stockholm) 2008, 89:137-148.

20. Wanninger A, Fuchs J, Haszprunar G: The anatomy of the serotonergic nervous system of an entoproct creeping-type larva and its phylogenetic implications. Invertebr Biol 2007, 126:268-278.

21. Fuchs J, Wanninger A: Reconstruction of the neuromuscular system of the swimming-type larva of Loxosomella atkinsae (Entoprocta) as inferred by fluorescence labelling and confocal microscopy. Org Divers Evol 2008, 8:325-335.

22. Schleip W: Die Determination der Primitiventwicklung (Leipzig, Akademische Verlagsgesellschaft). 1929.

23. Scheltema $\mathrm{AH}$ : Aplacophora as progenetic aculiferans and the coelomate origin of mollusks as the sister taxon of Sipuncula. Biol Bull 1993, 184:57-78.

24. Maslakova SA, Martindale MQ, Norenburg JL: Fundamental properties of the spiralian developmental program are displayed by the basal nemertean Carinoma tremaphoros (Palaeonemertea, Nemertea). Dev Biol 2004, 267:342-360

25. Hatschek B: Embryonalentwicklung und Knospung der Pedicellina echinata. Z Wiss Zool 1877, 29:502-549.

26. Marcus E: Bryozoários marinhos brasileiros III. Bol. Fac. Fil., Ciên. Letr. Univ. S. Paulo, XIII. Zool 1939, 3:111-354.

27. Malakhov W: Description of the development of Ascopodaria discreta (Coloniales, Barentsiidae) and discussion of the Kamptozoa status in the animal kingdom. Zool Zh 1990, 69:20-30.

28. Conklin EG: The embryology of Crepidula. J Morphol 1897, 13:1-226.
29. Goulding MQ: Cell lineage of the Ilyanassa embryo: evolutionary acceleration of regional differentiation during early development. PLOS One 2009, 4:e5506.

30. Henry JJ, Martindale MQ: Conservation and innovation in spiralian development. Hydrobiologia 1999, 402:255-265.

31. Kofoid CA: On some laws of cleavage in Limax: A preliminary notice. Proc Am Acad Arts Sci 1894, 29:180-203.

32. Heath H: The development of Ischnochiton. Zool Jb Anat Ontog Tiere 1898, 12:567-656.

33. Van Dongen CAM, Geilenkirchen WLM: The development of Dentalium with special reference to the significance of the polar lobe. I, II, III. Division chronology and development of the cell pattern in Dentalium dentale (Scaphopoda). Proc K Ned Akad Wet C 1974, 77:57-100.

34. Van den Biggelaar JAM, Dictus WJAG, van Loon AE: Cleavage patterns, cell-lineages and cell specification are clues to phyletic lineages in Spiralia. Sem Cell Dev Biol 1997, 8:367-378.

35. Okusu A: Embryogenesis and development of Epimenia babai (Mollusca Neomeniomorpha). Biol Bull 2002, 203:87-103.

36. Ponder WF, Lindberg DR: Phylogeny and evolution of the Mollusca Berkeley: University of California Press; 2008.

37. Guerrier $\mathrm{P}$, van den Biggelaar JAM, van Dongen CAM, Verdonk NH: Significance of the polar lobe for the determination of dorsoventral polarity in Dentalium vulgare (da Costa). Dev Biol 1978, 63:233-242.

38. Henry JJ, Collin R, Perry KJ: The slipper snail, Crepidula: An emerging lophotrochozoan model system. Biol Bull 2010, 218:211-229.

39. Van den Biggelaar JAM: Development of dorsoventral polarity and mesentoblast determination in Patella vulgata. J Morphol 1977, 154:157-186

40. Clement AC: Experimental studies on germinal localization in Ilyanassa. I. The role of the polar lobe in determination of the cleavage pattern and its influence in later development. J Exp Zool 1952, 121:593-625.

41. Luetjens CM, Dorresteijn AWC: Multiple, alternative cleavage patterns precede uniform larval morphology during normal development of Dreissena polymorpha (Mollusca, Lamellibranchia). Roux's Arch Dev Biol 1995, 205:138-149.

42. Holmes SJ: The early development of Planorbis. J Morphol 1900, 16:369-458.

43. Crampton HE: Reversal of cleavage in a sinistral gasteropod. Ann N Y Acad Sci 1894, 8:167-170

44. Kuroda R, Endo B, Abe M, Shimizu M: Chiral blastomere arrangement dictates zygotic left-right asymmetry pathway in snails. Nature 2009, 462:790-794.

45. Dohmen MR: Cell lineage in molluscan development. Microsc Res Tech 1992, 22:75-102.

46. Wilson EB: The cell-lineage of Nereis. A contribution to the cytogeny of the annelid body. J Morphol 1892, 6:361-480.

47. Wilson EB: Experimental studies in germinal localization. II. Experiments on the cleavage-mosaic in Patella and Dentalium. J Exp Zool 1904, 1:197-268.

48. Baba K: General sketch of the development in a solenogastre, Epimenia verrucosa (Nierstrasz). Misc Rep Res Inst Nat Resour (Tokyo) 1951, 1921:38-46.

49. Giribet $\mathrm{G}$ : Current advances in the phylogenetic reconstruction of metazoan evolution. A new paradigm for the Cambrian explosion? Mol Phylogenet Evol 2002, 24:345-357.

50. Drew GA: Some observations on the habitats, anatomy and embryology of members of the Protobranchia. Anat Anz 1899, 15:493-519.

51. Gustafson RG, Reid RGB: Development of the pericalymma larva of Solemya reidi (Bivalvia: Cryptodonta: Solemyidae) as revealed by light and electron microscopy. Mar Biol 1986, 93:411-427.

52. Gustafson RG, Lutz RA: Larval and early post-larval development of the protobranch bivalve Solemya velum (Mollusca: Bivalvia). J Mar Biol Assoc UK 1992, 72:383-402

53. Zardus J, Morse MP: Embryogenesis, morphology and ultrastructure of the pericalymma larva of Acila castrensis (Bivalvia: Protobranchia: Nuculoida). Invertebr Biol 1998, 117:221-244.

54. Rawlinson KA: Embryonic and post-embryonic development of the polyclad flatworm Maritigrella crozieri; implications for the evolution of spiralian life history traits. Front Zool 2010, 7:12

55. Newby WW: The early embryology of the echiuroid, Urechis. Biol Bull 1932, 63:387-399. 
56. Gerould JH: Studies on the embryology of the Sipunculidae. I. The embryonal envelope and its homologue. Mark Anniversary Volume 1903, 437-452.

57. Rice ME: A comparative study of the development of Phascolosoma agassizii, Golfingia pugettensis, and Themiste pyroides with a discussion of developmental patterns in the Sipuncula. Ophelia 1967, 4:143-171.

58. Tannreuther GW: The embryology of Bdellodrilus philadelphicus. J Morphol 1915, 26:143-216.

59. Sandig M, Dohle W: The cleavage pattern in the leech Theromyzon tessulatum (Hirudinea, Glossiphoniidae). J Morphol 1988, 196:217-252.

60. Costello DP, Henley C: Spiralian development: a perspective. Amer Zool 1976, 16:277-291.

61. Gerould JH: The development of Phascolosoma (Studies on the embryology of the Sipunculidae II). Zool Jb Anat Ontog Tiere 1906, 23:77-162.

62. Arenas-Mena C: Sinistral equal-size spiral cleavage of the indirectly developing polychaete Hydroides elegans. Dev Dyn 2007, 236:1611-1622.

63. Rouse GW, Fauchald K: The articulation of annelids. Zool Scripta 1995, 24:269-301.

64. McHugh D: Molecular evidence that echiurans and pogonophorans are derived annelids. Proc Nat Acad Sci USA 1997, 94:8006-8009.

65. MacBride EW: Textbook of Embryology. In Invertebrata. Volume 1. Macmillan \& Co., London; 1914

66. Mead AD: The early development of marine annelids. J Morphol 1897, 13:227-326.

67. Dawydoff C: Ontogénese des annelids. In "Traité de Zoologie" Edited by: Grassé PP 1959, 5:594-686.

68. Rice ME: Sipuncula. In: Reproduction of Marine Invertebrates. In Entoprocts and lesser coelomates. Volume 2. Edited by: Giese A, Pearse J. Academic Press, New York; 1975.

69. Boore JL, Staton JL: The mitochondrial genome of the sipunculid Phascolopsis gouldii supports its association with Annelida rather than Mollusca. Mol Biol Evol 2002, 19:127-137.

70. Halanych KM, Dahlgren TG, McHugh D: Unsegmented annelids? Possible origins of four lophotrochozoan worm taxa. Integr Comp Biol 2002, 42:678-684.

71. Helmkampf M, Bruchhaus I, Hausdorf B: Phylogenomic analyses of lophophorates (brachiopods, phoronids and bryozoans) confirm the Lophotrochozoa concept. Proc R Soc Lond B 2008, 275:1927-1933.

72. Kristof $A$, Wollesen $T$, Wanninger A: Segmental mode of neural patterning in Sipuncula. Curr Biol 2008, 18:1129-1132.

73. Wanninger A: Comparative lophotrochozoan neurogenesis and larval neuroanatomy: recent advances from previously neglected taxa. Acta Biol Hung 2008, 59(Suppl):127-136.

74. Kristof A, Wollesen T, Maiorova AS, Wanninger A: Cellular and muscular growth patterns during sipunculan development. J Exp Zool (Mol Dev Evol) 2011, 316:227-240.

75. Struck TH, Paul C, Hill N, Hartmann S, Hösel C, Kube M, Lieb B, Meyer A, Tiedemann R, Purschke G, Bleidorn C: Phylogenomic analyses unravel annelid evolution. Nature 2011, 471:95-98.

76. Henry JJ, Martindale MQ: Establishment of the dorsoventral axis in nemertean embryos: Evolutionary considerations of spiralian development. Dev Gen 1994, 15:64-78.

77. Maslakova SA, von Döhren J: Larval development with transitory epidermis in Paranemertes peregrina and other hoplonemerteans. Biol Bull 2009, 216:273-292.

78. Henry JJ, Martindale MQ: Conservation of the spiralian developmental program: Cell lineage of the nemertean, Cerebratulus lacteus. Dev Biol 1998, 201:253-269.

79. Boyer BC, Henry JQ, Martindale MQ: The cell lineage of a polyclad turbellarian embryo reveals close similarity to coelomate spiralians. Dev Biol 1998, 204:111-123.

80. Boyer BC, Henry JQ, Martindale MQ: Dual origins of mesoderm in a basal spiralian: Cell lineage analyses in the polyclad turbellarian Hoploplana inquilina. Dev Biol 1996, 179:329-338.

81. Emig CC: Embryology of Phoronida. Amer Zool 1977, 17:21-37.

82. Valentine JW: Cleavage pattern and the topology of the metazoan tree of life. Proc Natl Acad Sci USA 1997, 94:8001-8005.

83. Freeman G: Regional specification during embryogenesis in the inarticulate brachiopod Discinisca. Dev Biol 1999, 209:321-339.
84. Gruhl A: Ultrastructure of mesoderm formation and development in Membranipora membranacea (Bryozoa: Gymnolaemata). Zoomorphology 2010, 129:45-60.

85. Rattenbury JC: The embryology of Phoronopsis viridis. J Morphol 1954, 95:289-349.

86. Conklin EG: The embryology of a brachiopod, Terebratulina septentrionalis Couthouy. Proc Am Philos Soc 1902, 41:41-76.

87. Jenner RA: Unleashing the force of cladistics? Metazoan phylogenetics and hypothesis testing. Integr Comp Biol 2003, 43:207-218.

88. Zrzavy J: Gastrotricha and metazoan phylogeny. Zool Scr 2003, 32:61-81.

89. Hennig W: Taschenbuch der speziellen Zoologie, Teil 1. Wirbellose I. Ausgenommen Gliedertiere Thun und Frankfurt am Main: Verlag Harri Deutsch; 1983

doi:10.1186/1471-213X-12-11

Cite this article as: Merkel et al:: Spiral cleavage and early embryology of a loxosomatid entoproct and the usefulness of spiralian apical cross patterns for phylogenetic inferences. BMC Developmental Biology 2012 12:11.

\section{Submit your next manuscript to BioMed Central and take full advantage of:}

- Convenient online submission

- Thorough peer review

- No space constraints or color figure charges

- Immediate publication on acceptance

- Inclusion in PubMed, CAS, Scopus and Google Scholar

- Research which is freely available for redistribution 